\title{
Sören Kierkegaard se Godsdiensfilosofie
}

\author{
M W PRETORIUS
}

\section{Inleiding}

Die godsdienstige agtergrond vir Kierkegaard se Godsdiensfilosofie kan saamgevat word deur na twee sleutelfigure in die Christelike tradisie te verwys naamlik Paulus en Luther. Dit was veral hierdie twee wat die eis vir die outonomie van die godsdiens gestel het wat Kierkegaard (Climacus) so beslissend in Philosophical Fragments en Concluding Unscientific Postscript beïnvloed het. Om Kierkegaard enigsins te verstaan, is dit dus nodig om aandag aan hierdie twee belangrike figure te gee.

\section{Paulus se brief aan die Korintiërs as rigtinggewend}

Emil Brunner het in sy Philosophy of Religion from the Standpoint of Protestant Theology reeds opgemerk dat die klassieke en beslissende uitdrukking vir die ortodokse Protestantse opvatting van die verhouding tussen geopenbaarde godsdiens en krities-evaluerende filosofie gegee word in Paulus se Eerste brief aan die Korintiërs. Die sentrale gedagte van so 'n Godsdiensfilosofie is saamgevat in die beroemde gedeelte: "Wat die oog nie gesien en die oor nie gehoor en in die hart van 'n mens nie opgekom het nie, wat God berei het vir die wat Hom liefhet" (I Kor 2:9). Dieselfde gedagte vind ons ook in die Evangelie van Johannes uitgedruk: "Die wind waai waar hy wil, en jy hoor sy geluid, maar jy weet nie vanwaar hy kom en waarheen hy gaan nie. So is elkeen wat uit die Gees gebore is" (Joh 3:8). Wat dit beteken, word verder duidelik deur wat Paulus skryf: "Maar die natuurlike mens neem die dinge van die Gees van God nie aan nie; want dit is vir hom dwaasheid, en hy kan dit nie verstaan nie, omdat dit geestelik beoordeel word (I Kor 2:14). Daarom kan die "natuurlike mens", dit is die mens wat met niks meer as sy immanente denkvermoëns toegerus is; die mens wat nie oor 'n "geestelike oordeelsvermoë beskik nie, wat nie die "sin van Christus" het nie, nooit die boodskap van God wat aan ons geopenbaar is deur sy Gees, ken nie. As God nie sy waarheid aan die mens openbaar en hom ook die vermoë gee om dit te ken nie, kan geen mens ooit die waarheid ken nie.

Hierdie "geestelike oordeelsvermoë" wat deur God gegee word, is duidelik in teenstelling met wat Paulus "natuurlike wysheid" noem. Die "oorredende woorde van menslike wysheid" staan in teenstelling tot die ware geloof, "want die wysheid van hierdie wêreld is 
dwaasheid by God" (I Kor 3:19). Daarom sê Paulus: "Laat niemand homself mislei nie: as iemand meen dat hy wys is onder julle in hierdie wêreld, laat hom dwaas word, sodat hy wys kan word" (I Kor 3:18). Want "die gedagtes van die wyse mense" is nietig (I Kor 3:20). Om 'n ware Christen te wees, moet 'n mens glo, nie deur immanente wysheid nie, maar "in vrees en in veel bewing" (I Kor 2:3). (Kierkegaard het hier die titel van een van sy latere werke gevind: "Fear and Trembling").

Vir die verhouding tussen "natuurlike" en "geestelike" wysheid is daar twee baie belangrike punte in die redenasie van Paulus. Die eerste is dat daar ' $n$ radikale diskontinuïteit in die wêreld is. Die belangrikste is dit dat daar 'n radikale breuk bestaan tussen wat die menslike denke uit homself kan voortbring en die religieuse waarheid wat deur God aan die mense gegee word. Hiermee korreleer verder die breuk tussen die menslike denke self en die waarheid, in die opsig dat die "natuurlike wysheid" van die nie-gelowige, ook nadat hy die waarheid gehoor het, dit nog nie kan verstaan behalwe in en deur die geloof nie. Daarom moet afgelei word dat die "ware godsdiens" nie uit enige vorm van menslike refleksie, nog oor die wêreld, nóg oor homself nie, verkry kan word nie.

In hierdie idee van die radikale diskontinuïteit moet nog 'n ander aspek beklemtoon word. Die breuk tussen God en mens impliseer dat die menslike eksistensie oop is, so dat elke mens potensieel 'n skyf is vir die gawe van die Gees. Dit beteken dat elke "natuurlike" mens wysheid kan verkry waarvoor hy hom op geen manier kan voorberei of dit op geen wyse uit sy eie refleksie ontwikkel nie. Gevolglik kan hy die wysheid ook op geen wyse vanuit sy "natuurlike" refleksie verifieer nie.

Uit hierdie radikale diskontinuïteit volg dan die tweede belangrike punt. Indien die "natuurlike" mens eo ipso van die waarheid wat deur God in die openbaring en in genade gegee word, verstoke is, dan volg hieruit dat die normale kennisvermoë net nie die bevattingsvermoë vir die religieuse waarheid het nie. Indien die inhoud van die religieuse boodskap dan "dwaasheid" is, moet die mens saltu mortale maak, 'n sprong van die wêreldse verwagtings tot die geloof in die goddelike "dwaasheid". Die noodsaaklike "sin van Christus" kan dan alleen bekom word deur (1) die gawe van die Gees en (2) die menslike antwoord wat uit die opheffing van wêreldse wysheid bestaan of geloof as 'n metabasis eis allo genos.

\section{Die invloed van Luther}

Via, onder andere, Tertullianus het Luther ook die absolute verskil tussen God en mens beklemtoon en vasgehou aan die eenvoudige, anti-intellektuele geloof. Hierdie tradisie het hy voortgesit soos 
Rudolph Otto tereg van Luther opmerk: "God is altogether mysteriis suis et judiciis incomprehensibilibus: ( $\mathrm{He}$ is) in his essence hidden away from all reason, knows no measure, law, or aim, and is verified in the paradise" (R Otto, The Holy Trans John W Harvey 1961 p 101).

Luther het homself baie duidelik oor die verhouding tussen openbaring en rede uitgedruk: "And truly the magnitude of God's love for us engenders in us not only a hardness to believe but also incredulity itself. Therefore the Holy Scripture speaks of far other than philosophical matters, namely of unspeakable and utterly divine gifts, which far surpass the capacity of both men and angels" (H T Kerr, A Compend of Luther's Theology 1943 p 5). Hierdie uitspraak is sonder twyfel gegrond op die uitsprake van Paulus. Wat God gedoen het en nog doen vir mense is radikaal onbegrypbaar en onverwags. Die mens in sy "natuurlike" staat kan hom nie eers 'n voorstelling van die Inkarnasie maak nie, en al is dit 'n feit, bly dit nog 'n misterie. Daarom vra Luther: "Why do Christians use their natural reason and understanding, seeing it must be set aside in matters of faith, as not only not understanding them, but also as striving against them." Die natuurlike wysheid kan daarom nie slegs die openbaring nie begryp nie, maar werk ook die aanvaarding daarvan teen. Dit is so omdat die mens blind is deur die sonde. Hier gaan dit egter om die gevolge van die sonde, en nie om die sonde as feit wat baie belangrik is in die teologiese denke nie.

Luther hou dus daaraan vas dat alleen die Gees die voorwaarde skep vir die mens om die goddelike waarheid te kan aanneem. Om te kan glo, het ons die genadige werk van die Heilige Gees nodig - geloof is 'n gawe van God wat die mens nie uit homself kan verkry nie.

Luther het verder beklemtoon dat, alhoewel elke pre-religieuse of a-religieuse verstaan van die geopenbaarde waarheid onmoontlik is, ' $n$ mens nadat hy glo deur die geloof ' $n$ rasionele insig in die betekenis van die boodskap van die openbaring kan bekom. Maar hierdie insig is die funksie van 'n bonatuurlike genadegawe. As gevolg van die mens se eindigheid en sy sonde, kan hy die waarheid van God nie vind nie; sonder die lumen fide $i$ kan hy die waarheid nooit met sy denke eers benader nie, omdat die waarheid self eo ipso onkenbaar is sonder genade. Daar is ' $n$ radikale diskontinuilteit tussen God en mens, daarom is die openbaring noodsaaklik en bly dit ' $n$ aanstoot en 'n paradoks vir die mens sonder die gawe van goddelike wysheid.

\section{Die godsdiens in Kierkegaard se Godsdiensfilosofie}

Brunner beweer: "If anyone ever used the slogan Credo quia absordum, it was Kierkegaard" (Revelation and Reason p. 376). In 'n ander werk sê Brunner: "As all human action reveals the sinful heart, 
so all philosophical speculation, when left to itself, bears witness to the obscuration in the inmost recesses of our reason. For this reason it is impossible to build up the Christian proclamation of the Gospel and its theology on the basis of a philosophical doctrine of God. It was Kierkegaard alone among the great men of modern times who had the firm and vital hold on this truth (God and Man p 40).

Oor Luther het Kierkegaard gesê: “Luther's great discovery is that the relationship to God does not belong to the sphere of reason, but is an irrational, personal, spiritual relationship." (Aangehaal by Jolivet, Introduction to Kierkegaard p 206). Daarom kan die mens God nooit uit homself ken nie: ... "if man is to receive any true knowledge about the Unknown (God) he must be made to know that it is unlike him, absolutely unlike him. This knowledge the Reason cannot possibly obtain of itself; we have already seen that this would be a self-contradiction. It will therefore have to obtain this knowledge from God. But even if it obtains such knowledge it cannot understand it, and is quite unable to possess such knowledge. For how should the Reason be able to understand what is absolutely different from itself"' (Philosophical Fragments 1958 p 36-37), Wanneer Kierkegaard oor die Inkarnasie as sentrale Christelike leerstuk skryf, kom hy tot soortgelyke uitsprake: "No system of philosophy, addressing itself only to thought, no mythology, addressing itself solely to the immagination, no historical knowledge, addressing itself to the memory has ever had this idea: of which it may be said with all possible ambiquity in this connection, that it did not arise in the heart of any man" (Phil Frag p 92).

Hierdie boodskap is onbekend en onkenbaar omdat die mens weens sy sonde, God nie met sy natuurlike rede alleen kan ken nie hy is in 'n "state of error" ( $p$ 9). Weens die feit dat hy sondaar is, is die mens blind vir God en sy waarheid en moet God Homself openbaar. "Moved by love, God is thus eternally resolved to reveal himself" (Phil Frag p 19). Maar hierdie openbaring is nie 'n direkte openbaring van 'n rasionele waarheid nie. Dit is so weens die basiese onvergelykbaarheid van die sondige en eindige mens en die sondelose en oneindige God. Indien God 'n direkte rasionele waarheid in die openbaring sou gee, moes of die mens 'n god gemaak word om die waarheid te kan begryp of die mens sou mislei moes word om te dink dat hy goddellik is. Altwee sou egter die mens as outonome individu ophef (Phil Frag p 21-24).

Daarom moes God, gedring deur sy liefde, mens word. "For love is exultant when it unites equals, but it is triumphant when it makes that which was unequal equal in love" (Phil Frag $p 20$ ). So alleen kan die mens God leer ken "in the form of a servant" (Phil Frag p 24). Hierdie is nie maar net 'n kleed wat God aantrek nie. "It is his true form and figure" (Phil Frag p 25). Onder geen omstandighede kan 
die mens dit verkry of aflei uit sy "natuurlike" rede nie. Dit is 'n totaal ondenkbare gedagte dat God "would make himself into the likeness of man". Kierkegaard noem dit 'n "most stupid thought" (Phil Frag p 28). Oor hierdie onvergelykbaarheid en onverenigbaarheid van God en mens skryf Kierkegaard ook in Training in Christianity: "That an individual man is God is Christianity, and this individual man is the God-man. There is neither in heaven, nor on earth, nor in the depths, nor in the abberrations of the fantastic thinking, the possibility of a (humanly speaking) more insane combination" (p 85). Vir die "natuurlike" rede is hierdie Paradoks 'n absurditeit waarteen hy kan stoot: "The reason says that the Paradox is absurd, but this is mere mimicry, since the Paradox is the Paradox, quia absurdum" (Phil Frag p 42). In sy Concluding Unscientific Postscript werk Kierkegaard hierdie gedagte van die absurdum verder uit en betoog hy dat die feit dat God mens geword, ens, dat die ewige waarheid in die tyd gekom het, die eintlike absurdum is (Postscript p 188).

Indien die sentrale waarheid van die godsdiens, die openbaring sensu strictissimo van die paradoksale inkarnasie van God, 'n fundamentele beginsel is, dan volg dit ook hieruit dat die ooreenstemmende menslike antwoord, die geloof in die a-rasionele openbaring noodsaaklik is om die openbaring aan te neem en te verifieer. Hierdie geloofsbeslissing, die persoonlike benadering van die paradoksale boodskap met die hulp van die Gees, is die enigste antwoord moontlik, dit is ' $n$ sprong in objektiewe onsekerheid. Kierkegaard het van die geloof in die a-rasionele God 'n beroemd geworde definisie gegee: "An objective uncertainty held fast in an appropiationprocess of the most passionate in wardness is the truth" (Postscript $p$ 182). Die enigste regte en moontlike wenslike antwoord is hierdie hartstogtelike saltus mortalis, hierdie metabasis eis allo genos (Postscript $\mathrm{p}$ 90). Dit is 'n sprong juis vanweë die radikale diskontinuïteit tussen God en mens. Daarom dat die geloof ooreenkom met die a-rasionaliteit van sy objek wat vir die mens se "natuurlike" rede nooit begrypbaar kan wees nie.

Hierdie geloof met so 'n objek, maak dit noodsaaklik dat God ook die voorwaarde om te kan glo, moet skenk - dit is genade. Dit kan dan as't ware net teen die rede geglo word, want die genade kom van buite die rede: "Looked at from any other point of view, Christianity is and must remain the greatest honor or a sort of madness. Only through the consciousness of sin is there entrance to it, and the wish to enter it in any other way is the crime of lese-majeste against Christianity" (Training in christianity p 71).

Dit het dus tot sover geblyk dat daar 'n radikale diskontinuïteit tussen God en mens, tussen menslike wysheid en sy verwagtings en goddelike wysheid en sy openbaring, bestaan. Hierdie breuk wat 
die gevolg is van die sonde en eindigheid van die mens, kan alleen deur die openbaring sensu strictissimo, die God-mens, Jesus Christus, geheel word.

Hierdie a-rasionele verskyning van God in die geskiedenis en eindigheid kan alleen aangeneem word, en die breuk geheel word indien die mens God vertrou deur die sprong buite en teen die verwagtings van die eindige (natuurlike) begrip. Die sprong kan slegs met behulp van God plaasvind, aangesien die mens nog die vermoë nog die begeerte het om sy immanente sekerhede op te hef. Daarom vorm die openbaring sensu strictissimo en die geloofsprong die uitstaande kenmerke van hierdie godsdiens.

Kierkegaard som hierdie vereistes in ' $n$ inskrywing in sy dagboek so op: Faith cannot be proved, substantiated, and grasped by the mind, just because it lacks the necessary joints which makes possible any linking-together, and how can you describe this except by calling it paradox? For the desultory (disconnected) element in the paradox is just this, that it lacks continuity, or anyway only has continuity backwards; that is to say, doesn't have any continuity from the start ... (i.e.) ... the paradox has never 'arisen' in any man's heart, though afterwards he can grasp it, never forgetting, however, that it did not originate in himself" (Journal Vol V, C vertaal deur T H Croxall 1958). Die geloof sowel as sy objek, die paradoks, mis enige kontinuilteit met die immanente rede.

\section{Samevatting}

In die voorafgaande betoog is dit duidelik dat Kierkegaard in 'n Godsdiensfilosofie die plek van die geopenbaarde godsdiens veilig sal stel sonder om dit enigsins te reduseer. Dit is vir hom ' $n$ absolute voorvereiste dat die outonomie van die geopenbaarde godsdiens gehandhaaf moet word.

Maar dit is juis in die raamwerk van die betoog tot sover belangrik om daarop te let dat Kierkegaard die pseudoniem Johannes Climacus gebruik. Hierdie Climacus maak hoofsaaklik van die "leer" van die dialektiese rede gebruik en daarom neem hy 'n posisie in tussen die spekulatiewe filosofie aan die een kant en die geopenbaarde godsdiens aan die ander kant. Climacus het sy taak vir homself so beskryf: "to discover where the misunderstanding lies between speculative philosophy and Christianity" (Postscript p 216). Hy is nie 'n Christen nie en ook nie 'n spekulatiewe filosoof nie, maar juis daarom probeer hy om die twee in verhouding tot mekaar te bring sonder om albei skeef te trek of te reduseer. (In hierdie artikel gaan dit net om die een kant naamlik die plek en waarde van die geopenbaarde godsdiens. In ' $n$ volgende artikel sal aan die verhouding tot die spekulatiewe aandag gegee word). 
God moes mens word - in die tyd kom - om die waarheid te openbaar. Daarom moet die mens die twee absurditeite aanvaar:

dat hy die waarheid nie in homself het nie; dat hy ' $n$ sondaar is, (dat hy 'n sondaar is, kon hy ook nie deur sy natuurlike rede leer nie), en

hierdie waarheid moes van buite homself, van God in die tyd kom.

Dit is die Absolute Paradoks, die totaal absurde voorwaarde van die Christendom, dat die essensiële enige waarheid vir alle mense hang aan die een kontingente, historiese mens, omdat hierdie mens ook God is (Postscript 288-290).

In hierdie beskrywing van die godsdiens sien ons dat Climacus deur "a sort of nimble dancing in the service of Thought" (Phil Frag p 3) alle moontlikhede van 'n verbinding van die reflektiewe en die Christelike godsdiens wou afsny: "Faith constitutes a sphere all by itself, and every misunderstanding of Christianity may at once be recognised by its transforming it into a doctrine, transferring it to the sphere of the intellectual" (Postscript p 291).

Vir enige Godsdiensfilosofie het Kierkegaard dus hier, deur Climacus, een van die belangrikste voorwaardes gestel naamlik die uniekheid en onherleibaarheid van die Christelike godsdiens. Tussen die "natuurlike" rede (en die natuurlike godsdiens) gaap daar'n onoorbrugbare kloof. Hierdie kloof kan alleen oorbrug word deur die sprong van die geloof - "the absolute venture and the absolute risk" (Postscript p 384). 